The Open Dentistry Journal
CrossMark
Content list available at: www.benthamopen.com/TODENTJ/
DOI: $10.2174 / 1874210601610010166$

\title{
Green Tea (Camellia Sinensis): Chemistry and Oral Health
}

\author{
Zohaib Khurshid, ${ }^{1}$ Muhammad S. Zafar ${ }^{2, *}$, Sana Zohaib ${ }^{3}$, Shariq Najeeb ${ }^{4}$ and Mustafa Naseem ${ }^{5}$ \\ ${ }^{I}$ Department of Dental Biomaterials, College of Dentistry, King Faisal University, Al-Hafuf, Saudi Arabia \\ ${ }^{2}$ Department of Restorative Dentistry, Taibah University College of Dentistry, Madinah Al Munawwarah, Saudi Arabia \\ ${ }^{3}$ Department of Biomedical Engineering, King Faisal University, Al-Hofuf, Saudi Arabia \\ ${ }^{4}$ School of Clinical Dentistry, University of Sheffield, Sheffield, UK \\ ${ }^{5}$ Department of Community and Preventive Dentistry, Ziauddin University, Karachi, Pakistan
}

\begin{abstract}
Green tea is a widely consumed beverage worldwide. Numerous studies have suggested about the beneficial effects of green tea on oral conditions such as dental caries, periodontal diseases and halitosis. However, to date there have not been many review articles published that focus on beneficial effects of green tea on oral disease. The aim of this publication is to summarize the research conducted on the effects of green tea on oral cavity. Green tea might help reduce the bacterial activity in the oral cavity that in turn, can reduce the aforementioned oral afflictions. Furthermore, the antioxidant effect of the tea may reduce the chances of oral cancer. However, more clinical data is required to ascertain the possible benefits of green tea consumption on oral health.
\end{abstract}

Keywords: Antimicrobial, caries, dental care, periodontitis, tobacco.

\section{INTRODUCTION}

Before the development of pharmaceutical industry, herbal products were used for curing various conditions. The concept of using natural and herbal products is very old. Humans have used these products for curing various diseases and become popular accordingly. In terms of oral care, most commonly used herbal product is "Miswak" that become popular in several communities as an effective, cheap and efficient way of maintaining oral hygiene [1 - 4]. Similarly, beneficial effects of using various types of tea leaves have been a common topic of discussion in general public and professionals. According to Chinese legend, tea has a known history of over 4000 years ago which was discovered accidentally by an emperor, while according to other sources the Chinese have been drinking tea since 3000 B.C. and over millions of acres are devoted to its cultivation. Currently, it is being used in almost every country around the world and is now been grown in India, Sri Lanka, Iran, Java and Japan [5].

Green tea (botanical name of tea plant is Camellia Sinensis) belonging to the family Theaceae (Table 1) has been explored in the recent years for its beneficial effects on oral health. It can be available as a shrub or evergreen tree. Its leaves may vary from exstipulate, lanceolate to obovate up to $30 \mathrm{~cm}$ long, $2-5 \mathrm{~cm}$ broad, pubescent, sometimes becoming glabrous, serrate, acute or acuminate [6].

According to an estimate, daily consumption of tea is more than 3 billion cups; almost 75 percent consumption by China [7]. The standard method defined in Chinese culture is illustrated Fig. (1). Tea leaves are available in a variety of forms depending on processing techniques illustrated in Fig. (2) [8]. Dissimilarity between green tea and black tea is due to processing methods adopted during manufacturing. As a consequence of fermentation of black tea, chemical substance known as catechins (i.e. polyphenols with molecular weight less than 450Da) are oxidized and condensed while these are present in green tea. A third type of tea, known as oolong, contains mixture of monomeric and

\footnotetext{
* Address correspondence to this author at the Department of Restorative Dental Sciences, Taibah University College of Dentistry, P.O. Box 2898, Al Madinah Al Munawwarah, 41311, Saudi Arabia; Tel: 00966507544691; E-mail: drsohail_78@hotmail.com
} 
oligomeric catechins and is in semi fermented form [9].

Distinctive composition of green is listed in Table 2 [10, 11]. It is reported that one third part of bioactive compounds in green tea is contributed by polyphenols that is the most interesting constituent [12]. The main type of polyphenols are called catechins (flavan-3-ols) also known as tannins serve as astringency constituent. Dr. Michiyo Tsujimura extracted the catechins from tea leaves in 1929 and studied their functions (Fig. 3) for the first time during his work at The Institute of Physical and Chemical Research, Japan.

Most important kind of catechins include epigallocatechin-3-gallate (EGCG; 59\%), epigallocatechin (EGC; 19\%), epicatechin-3-gallate (ECG; 13.6\%) and epicatechin (EC; 6.4\%) including EGCG and EGC are reported for their presence in green tea. Both the types along with ECG exhibit antimicrobial activity [13]. ECG reviles the possibility of protection against urinary tract infections (UTI) as it is reported to be excreted by kidney while it is also extracted in bile along with EGCG. Large variations can be observed in the chemical structures of catechins due to dissimilar composition (Fig. 4). Green tea also serves as a great source of anti-oxidants.

Numerous therapeutic effects of green tea are reported after human clinica trials $[13,14]$. It contributes to improved oral health and decreases the chances of cardiovascular diseases, cancer and acts as an anti-hypertensive, anti-bacterial, anti-viral agent. It also exhibits protection against ultraviolet radiations, helps in weight loss, causes increase in bone mineral density and provides neuro-protective power. Other than the mentioned advantages of green tea, it is popularly utilized for the treatment of stomach discomfort, indigestion, vomiting, diarrhea and flatulence. It also enhances brain functioning and helps in maintaining blood glucose balance and body weight [15]. Due to numerous health benefits, there has been a significant increase in the popularity and consumption of green tea among various cultures and populations.

Table 1. Classification of green tea plant.

\begin{tabular}{|c|c|}
\hline Kingdom & Plantae \\
\hline Subkingdom & Tracheobionta \\
\hline Super-division & Spermatophyte \\
\hline Division & Magnoliophyta \\
\hline Class & Magnoliopsida \\
\hline Sub-class & Dillenidea \\
\hline Order & Theales \\
\hline Family & Theaceae \\
\hline Genus & Camellia L. \\
\hline Species & Camellia Sinensis \\
\hline
\end{tabular}

\section{GREEN TEA EFFECT ON ORAL TISSUES}

Green tea which is essential source for providing polyphenol antioxidants has the ability to protect against various oral diseases such as dental caries, gingivitis, periodontitis, halitosis and oral malignancy (protection and regression). In addition it can prevent from oral oxidative stress, inflammation resulting due to cigarette smoke and reduces dentin erosion and abrasion. The therapeutic roles of green tea related to oral health are given.

\section{a) Role as Antioxidants}

Polyphenols have shown anti-oxidative activity by neutralization of free radicals in the body. They are also known to reduce or prevent their detrimental effects and restrain ROS generation to inhibit the lysosomal secretions. The hydrogen releasing property of catechin and epicatechin results in scavenging effects [16]. Polyphenols have following processes that reduce oxidation level (Fig. 5).

\section{b) Therapeutic Effects on Periodontal and Gingival Health}

The gingival crevice is a physiological zone surrounded by gingiva and tooth margins. A colony of microorganisms resides in this space and most common of that are anaerobes. In pathological conditions, these spaces extend and periodontal pockets filled with serum exudates and large colonies of polymorphs. Additionally, oxidative stress supports the development of diseased conditions. The microbes commonly present in such conditions are Prevotella spp and Porphyromonas gingivalis (black pigmented anaerobes) [18].

Periodontal health is inversely related to consumption of green tea, an epidemiological study proves that people 
have better periodontal health if they drink green tea very often for example during meals or at breaks from work [19]. Green tea plays supportive role in the maintenance of periodontal health, as suggested by an in vitro study catechins (e.g. EGCG) restrict the development and colonization of harmful bacteria such as Porphyromonas gingivalis, Prevotella intermedia, and Prevotella nigrescens [20]. These bacteria cause severe harm to periodontal tissues for example Porphyromonas gingivalis develop adhesion to buccal mucosa and cause destruction [21]. Recently, Nadeem et al. [22] studied the influence of green tea consumption versus black tea on periodontal health of 240 dental students and noticed that students who were consuming green tea had good periodontal health status with minimal plaque accumulation in comparison with consumers of black tea. Literature exhibited that better periodontal health status of regular green tea using individuals is mainly due to catechins, as these are steric structures of 3-galloyl radial, ECG, EGCG and gallocatechin gallate (GCG) (major polyphenols) and responsible for restrain release of toxic end metabolites from Porphyromonas gingivalis [23].

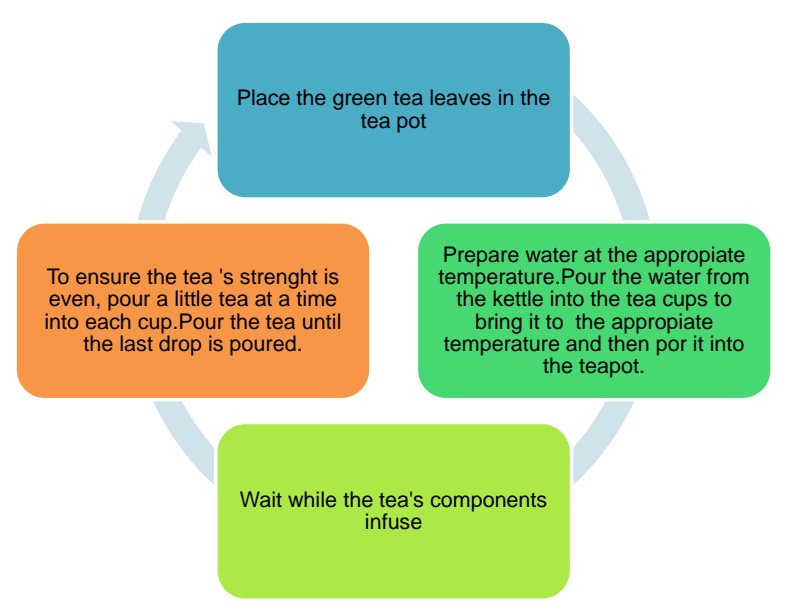

Fig. (1). Standard method to make green tea in chinese history.

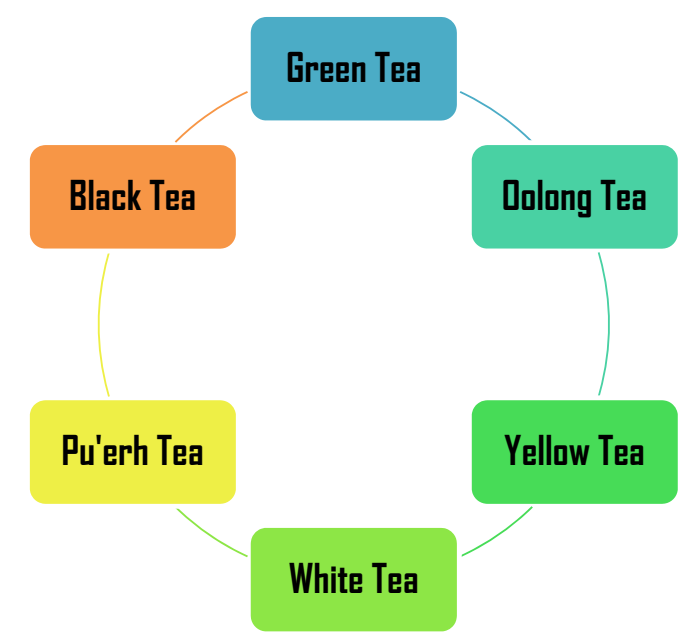

Fig. (2). Different kinds of tea according to their processing.

\section{c) Dental Caries}

Dental carries is a pathological condition resulting due to demineralization of tooth structure because of bacterial infections and/or deficiency of nutrients. Oral microbes are responsible for carries development, out of which mainly streptococcus mutants are most active [24]. The oral antimicrobial peptides are known to reduce the bacterial activity [25]. Green tea leaves are known to be rich in fluoride and other components such as polyphenols (catechins) that play a supportive role in resisting dental carried as reported in many studies [23, 26 - 28]. The beneficial role of fluoride is well known as it inhibits the bacterial growth and helps re-mineralization of dental tissues [29, 30]. Cariogenic bacteria 
release glucans with the help of glucosyltransferase (GTase) which are branched and facilitate adherence of microbes to tooth surface [24]. GC and EGC are the catechins that restrict the growth of 10 types of carries causing bacteria. Otake et al. [31] showed that total amount of catechins, mainly EGCG and its epimer gallocatechin, EC and ECG present in one cup of green tea prevent streptococcus mutants from adhering to tooth surfaces. The catechins were extracted from green tea with concentration of $100 \mathrm{mg} / \mathrm{L}$ and their effects on bacterial adhesion to salivary coated hydroxyapatites were observed. Other studies also exhibit that consumption of tea constrains the release of salivary enzyme, amylase as observed by Kashket and Paolino [32]. Later it was supported by Zhang and Kashket [33] proving that tea, either black or green restrains the enzymatic activity of Streptococcus mutans' amylase on tooth structure preventing deminerlization.

Fig. (3). Functions of catechins in human body.

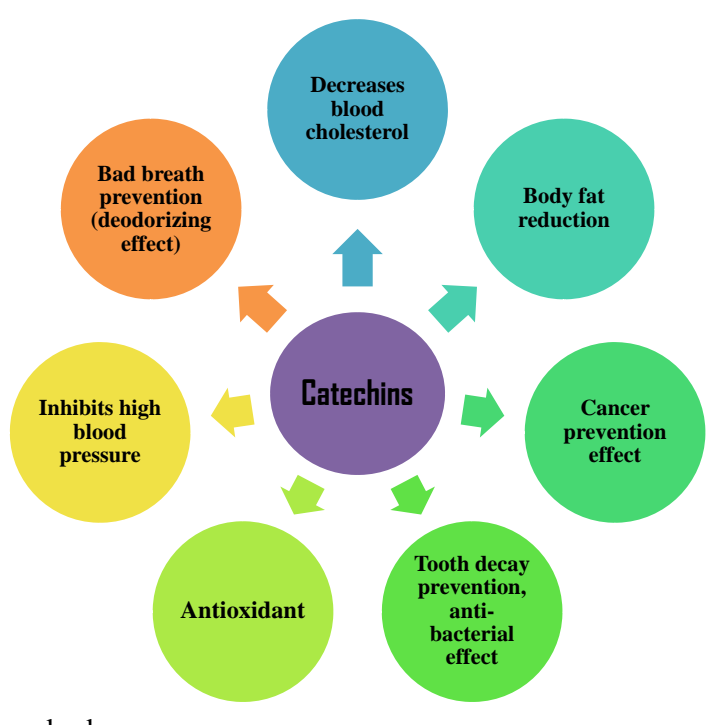

\section{d) Bad Breath (halitosis)}

The main reagents responsible for halitosis (bad breath) are volatile sulfide compounds such as hydrogen sulfide $\left(\mathrm{H}_{2} \mathrm{~S}\right)$, dimethylsulfide $\left[\left(\mathrm{CH}_{3}\right)_{2} \mathrm{~S}\right]$ and methyl mercaptan $\left(\mathrm{CH}_{3} \mathrm{SH}\right)$. These reagents degrade in the oral cavity by proteolytic reactions primarily by anaerobic gram negative bacteria consuming numerous sulfur-containing substrates including saliva, food debris, epithelial cells and blood [34]. Green tea is well known for antibacterial properties against anaerobic microorganisms. Green tea can abolish bad breath by suppressing anaerobic bacteria and eliminating the production of volatile sulfur compounds [35]. Deodorant action of ingredients decreases in the following order: EGCG $>\mathrm{EGC}>\mathrm{ECG}>\mathrm{EC}$. The deodorizing action of EGCG is based on a chemical reaction of EGCG and MSH and introducing methylsulfinyl/methylthio group into the B ring of EGCG. During this reaction, a methylthio group is supplemented in orthoquinone form of the catechin produced by oxidation, hence eliminating the halitosis [36].

Table 2. Chemical composition of green tea plant.

\begin{tabular}{|c|c|}
\hline Protein & Peptides and enzymes \\
\hline Carbohydrates & Fructose, sucrose, cellulose, pectin and glucose \\
\hline Vitamins & Vitamins (B, C, and E) \\
\hline Xanthic bases & Caffeine, Theophylline \\
\hline Pigments & Chlorophyll, Carotenoids \\
\hline Minerals and trace elements & Calcium, Magnesium, Sodium, Chromium, Manganese, Copper, Cobalt, Nickel, Iron, Molybdenum, Selenium, \\
Phosphorus, Potassium, Fluoride, Zinc, Aluminum
\end{tabular}

\section{e) Cigarette Smoke Induced Inflammation}

Smoking affects the homeostasis and injurious to oral health [37, 38]. The effects of smoking range from simple mucosal erythema to premalignant conditions and oral cancer. Smoking intensifies oral malignancies in response to oral inflammatory diseases due to compromised status of salivary antioxidants [39]. Diminished activity of numerous salivary enzymes is observed during smoking hence compromising the protection against oxidative damage [17]. In addition, smoke coming from tobacco comprised of reactive oxygen species (ROS) including superoxides, hydroxyl 
radical/hydrogen peroxide. The toxicity is further added due to the formation of nitric oxide (NO). Superoxide reacts chemically with NO to form peroxynitrite (ONOO). The inflammatory transcription factor pathway (NFkB) is triggered by ONOO due to activation of IkB kinase (IKK). The cascade of changes results in the intensification of expressions, iNOS activity and chronic inflammation in tissues even by exposing to a very minute dose of smoke [40].

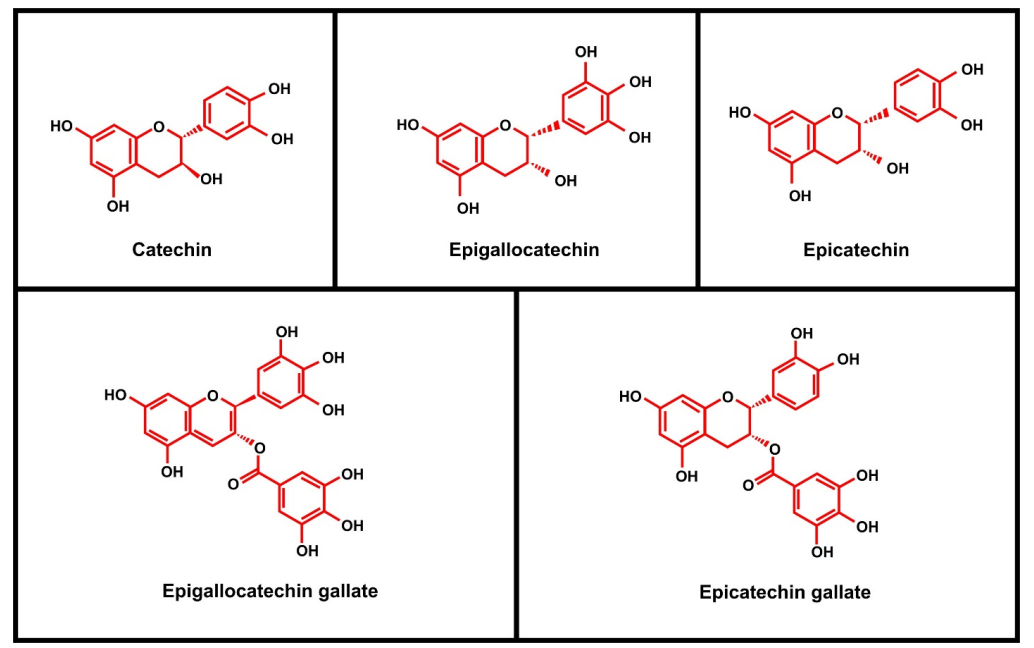

Fig. (4). Chemical structures of catechin and its family.

Green tea can be beneficial for cigarette smokers. Catechins present in green tea are capable of scavenging superoxide oxide, NO, and ONOO [41, 42]. In addition, EGCG has the ability to suppress activation of NF-kB that leads to inhibition of phosphorylation. It can further trigger the collapse of the inhibitory sections IkB-a in human pulp cells. The IkBa is also accountable for overturning nuclear transfer of NF-kB operating subunits (p65 and p50) and stimulation of pro-inflammatory genes [43, 44]. EGCG resulted in decreased NF-kB expression and reduction of proteins facilitated including matrix metalloproteinase9 (MMP-9). The MMP-9 is implicated in the breakdown of extracellular matrix, nterleukin-8 (IL-8) and iNOS present in bronchial epithelium [14]. There are more than 4700 oxygen/nitrogen species and reactive chemical compounds in the cigarette smoke. Nicotine is the main chemical compound released from cigarettes that affects gingival and periodontal health [45]. Nicotine stimulates apoptosis across ROS generations of human gingival fibroblasts (HuGF) [45]. The metabolites of nicotine such as tobaccospecific nitrosamines (TSNAs) are considered major carcinogens.

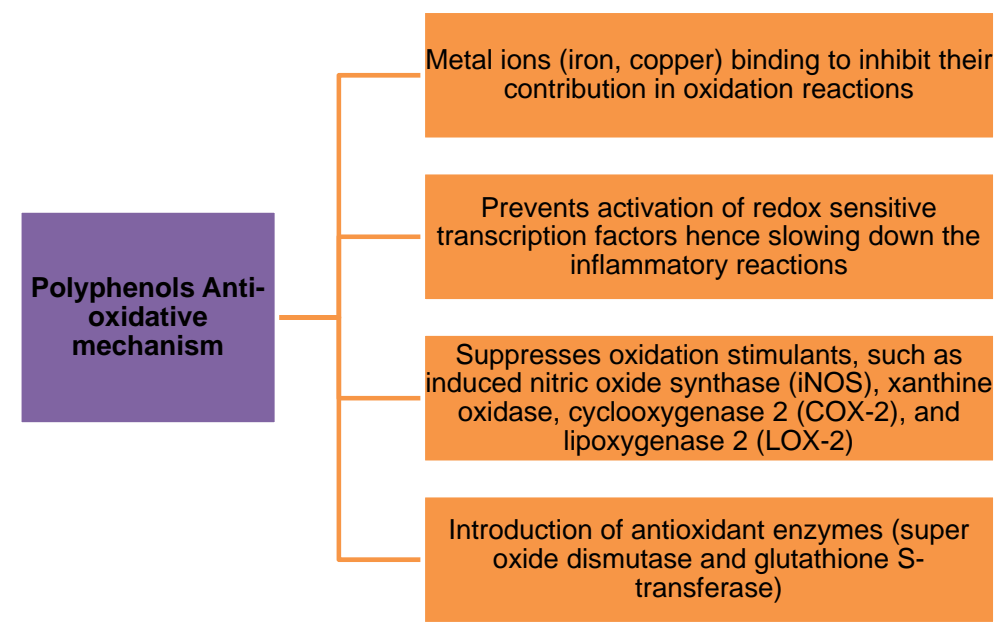

Fig. (5). Representing steps of oxidative reduction mechanism by polyphenols.

Weitberg et al. [46] treated cultured human pulmonary cells through EGCG prior to introducing to TSNA 4(Nmethyl- N-n-trosamino)-1-(3-pyridyl)-1-butanone (NNK). EGCG exhibited the ability to protect against the initiation 
of genetic injury to DNA of cultivated human pulmonary cells [46]. Another smoke compound (acrolein) is a risk factor for developing periodontal diseases and toxic to HuGF. It inhibits normal functioning of gingival fibroblasts due to interruption with cells attachment and proliferation [47]. In advance stages, acrolein can prompt inflammatory conditions and cancer onset. Green tea extract and EGCG can extinguish acrolein and other unsaturated aldehydes, hence reducing acrolein toxicity [48]. Green tea consumption can diminish oxidative and inflammatory tissue injuries in the oral cavity caused by cigarette smoking.

\section{CONCLUSION}

There are numerous beneficial effects of green tea on oral health. Green tea has valuable effects on oral conditions such as dental caries, periodontal disease and halitosis. Research suggests that green tea helps to reduce the bacterial activity in the oral cavity that in turn, can reduce the aforementioned oral afflictions. Furthermore, the antioxidant effect of the tea may reduce the chances of oral cancer in tobacco users. However, more clinical data is require to ascertain benefits of using green tea for oral tissues and prevention of oral diseases

\section{CONFLICT OF INTEREST}

The authors confirm that this article content has no conflict of interest.

\section{ACKNOWLEDGEMENTS}

Declared none.

\section{REFERENCES}

[1] Almas K. Miswak (chewing stick) and its role in oral health. Postgrad Dent 1993; 3: 214-8.

[2] Al-Bayaty FH. AI-Koubaisi AH, Ali Naw, Abdulla MA. Effect of mouth wash extracted from Salvadora persica (Miswak) on dental plaque formation: A clinical trial. J Medicinal Plants Res 2010; 4(14): 1446-54.

[3] Sofrata A, Lingström P, Baljoon M, Gustafsson A. The effect of miswak extract on plaque pH. An in vivo study. Caries Res 2007; 41(6): 451-4. [http://dx.doi.org/10.1159/000107931] [PMID: 17823507]

[4] Batwa M, Bergstrom J, Batwa S, Al-Otaibi MF. The effectiveness of chewing stick miswak on plaque removal. Saudi Dent J 2006; 18(3): $125-33$.

[5] Duke JA, Atchley AA. CRC handbook of proximate analysis tables of higher plants. USA: CRC Press 1986.

[6] Ferrara L, Montesano D, Senatore A. The distribution of minerals and flavonoids in the tea plant (Camellia sinensis). Farmaco 2001; 56(5-7): $397-401$.

[http://dx.doi.org/10.1016/S0014-827X(01)01104-1] [PMID: 11482766]

[7] Chen L, Zhou ZX. Variations of main quality components of tea genetic resources [Camellia sinensis (L.) O. Kuntze] preserved in the China National Germplasm Tea Repository. Plant Foods Hum Nutr 2005; 60(1): 31-5. [http://dx.doi.org/10.1007/s11130-005-2540-1] [PMID: 15898357]

[8] Banerjee S, Chatterjee J. Efficient extraction strategies of tea (Camellia sinensis) biomolecules. J Food Sci Technol 2014 ; pp. 1-11.

[9] Hamilton-Miller JM. Anti-cariogenic properties of tea (Camellia sinensis). J Med Microbiol 2001; 50(4): $299-302$. [http://dx.doi.org/10.1099/0022-1317-50-4-299] [PMID: 11289514]

[10] Cabrera C, Artacho R, Giménez R. Beneficial effects of green tea-a review. J Am Coll Nutr 2006; 25(2): 79-99. [http://dx.doi.org/10.1080/07315724.2006.10719518] [PMID: 16582024]

[11] Astill C, Birch MR, Dacombe C, Humphrey PG, Martin PT. Factors affecting the caffeine and polyphenol contents of black and green tea infusions. J Agric Food Chem 2001; 49(11): 5340-7. [http://dx.doi.org/10.1021/jf010759+] [PMID: 11714326]

[12] Mahmood T, Akhtar N, Khan BA. The morphology, characteristics, and medicinal properties of Camellia sinensis' tea. J Med Plants Res 2010; 4(19): 2028-33.

[13] McKay DL, Blumberg JB. The role of tea in human health: an update. J Am Coll Nutr 2002; 21(1): 1-13. [http://dx.doi.org/10.1080/07315724.2002.10719187] [PMID: 11838881]

[14] Syed DN, Afaq F, Kweon MH, et al. Green tea polyphenol EGCG suppresses cigarette smoke condensate-induced NF-kappaB activation in normal human bronchial epithelial cells. Oncogene 2007; 26(5): 673-82. [http://dx.doi.org/10.1038/sj.onc.1209829] [PMID: 16862172]

[15] Namita P, Mukesh R, Vijay KJ. Camellia Sinensis (green tea): a review. Global J Pharmacol 2012; 6: 52-9.

[16] Nugala B, Namasi A, Emmadi P, Krishna PM. Role of green tea as an antioxidant in periodontal disease: The Asian paradox. J Indian Soc Periodontol 2012; 16(3): 313-6. 
[http://dx.doi.org/10.4103/0972-124X.100902] [PMID: 23162321]

[17] Narotzki B, Reznick AZ, Aizenbud D, Levy Y. Green tea: a promising natural product in oral health. Arch Oral Biol 2012; 57(5): 429-35. [http://dx.doi.org/10.1016/j.archoralbio.2011.11.017] [PMID: 22226360]

[18] Chapple IL. Reactive oxygen species and antioxidants in inflammatory diseases. J Clin Periodontol 1997; 24(5): 287-96. [http://dx.doi.org/10.1111/j.1600-051X.1997.tb00760.x] [PMID: 9178107]

[19] Kushiyama M, Shimazaki Y, Murakami M, Yamashita Y. Relationship between intake of green tea and periodontal disease. J Periodontol 2009; 80(3): 372-7. [http://dx.doi.org/10.1902/jop.2009.080510] [PMID: 19254120]

[20] Makimura M, Hirasawa M, Kobayashi K, et al. Inhibitory effect of tea catechins on collagenase activity. J Periodontol 1993; 64(7): 630-6. [http://dx.doi.org/10.1902/jop.1993.64.7.630] [PMID: 8396176]

[21] Magnusson I, Lindhe J, Yoneyama T, Liljenberg B. Recolonization of a subgingival microbiota following scaling in deep pockets. J Clin Periodontol 1984; 11(3): 193-207. [http://dx.doi.org/10.1111/j.1600-051X.1984.tb01323.x] [PMID: 6368611]

[22] Nadeem M, Datoo F, Bugti AA, Ayaz A, Mahfooz M. Effects of black tea and green tea on periodontal health status among dental students at pakistan 2014.

[23] Sakanaka S, Okada Y. Inhibitory effects of green tea polyphenols on the production of a virulence factor of the periodontal-disease-causing anaerobic bacterium Porphyromonas gingivalis. J Agric Food Chem 2004; 52(6): 1688-92. [http://dx.doi.org/10.1021/jf0302815] [PMID: 15030231]

[24] Hamada S, Slade HD. Biology, immunology, and cariogenicity of Streptococcus mutans. Microbiol Rev 1980; 44(2): 331-84. [PMID: 6446023]

[25] Khurshid Z, Naseem M, Sheikh Z, Najeeb S, Shahab S, Zafar MS. Oral Antimicrobial Peptides: Types and Role in the Oral Cavity. Saudi Pharmaceut J 2015. [In press]

[http://dx.doi.org/10.1016/j.jsps.2015.02.015.]

[26] Wu C, Wei G, Wilson M. Tea as a functional food for oral health. Food constituents and oral health. In: Wilson M, Ed. Food constituents and oral health: Epigallocatechin gallate Suppresses Cariogenic Viru- Current status and future prospects. Florida, U.S.A.: CRC Press LLC 2009; pp. 396-417.

[http://dx.doi.org/10.1533/9781845696290.2.396]

[27] Sakanaka S, Kim M, Taniguchi M, Yamamoto T. Antibacterial substances in Japanese green tea extract against Streptococcus mutans, a cariogenic bacterium. Agric Biol Chem 1989; 53(9): 2307-11.

[28] Sakanaka S, Sato T, Kim M, Yamamoto T. Inhibitory effects of green tea polyphenols on glucan synthesis and cellular adherence of cariogenic streptococci. Agric Biol Chem 1990; 54(11): 2925-9.

[29] Zafar MS, Ahmed N. Therapeutic roles of fluoride released from restorative dental materials Res Rev Fluoride 2015; 48(3): 184-94.

[30] Zafar MS. Effects of surface pre-reacted glass particles on fluoride release of dental restorative materials. World Appl Sci J 2013; 28(4): $457-62$.

[31] Otake S, Makimura M, Kuroki T, Nishihara Y, Hirasawa M. Anticaries effects of polyphenolic compounds from Japanese green tea. Caries Res 1991; 25(6): 438-43. [http://dx.doi.org/10.1159/000261407] [PMID: 1667297]

[32] Kashket S, Paolino VJ. Inhibition of salivary amylase by water-soluble extracts of tea. Arch Oral Biol 1988; 33(11): 845-6. [http://dx.doi.org/10.1016/0003-9969(88)90110-0] [PMID: 2476976]

[33] Zhang J, Kashket S. Inhibition of salivary amylase by black and green teas and their effects on the intraoral hydrolysis of starch. Caries Res 1998; 32(3): 233-8. [http://dx.doi.org/10.1159/000016458] [PMID: 9577990]

[34] Tonzetich J. Production and origin of oral malodor: a review of mechanisms and methods of analysis. J Periodontol 1977; 48(1): 13-20. [http://dx.doi.org/10.1902/jop.1977.48.1.13] [PMID: 264535]

[35] Liao S, Kao YH, Hiipakka RA. Green tea: biochemical and biological basis for health benefits. Vitam Horm 2001; 62: 1-94. [http://dx.doi.org/10.1016/S0083-6729(01)62001-6] [PMID: 11345896]

[36] Yasuda H, Arakawa T. Deodorizing mechanism of (-)-epigallocatechin gallate against methyl mercaptan. Biosci Biotechnol Biochem 1995; 59(7): 1232-6. [http://dx.doi.org/10.1271/bbb.59.1232]

[37] Javed F, Al-Rasheed A, Almas K, Romanos GE, Al-Hezaimi K. Effect of cigarette smoking on the clinical outcomes of periodontal surgical procedures. Am J Med Sci 2012; 343(1): 78-84. [http://dx.doi.org/10.1097/MAJ.0b013e318228283b] [PMID: 21804361]

[38] Fahad K, Aziz A, Shahab S, Zafar M. Laboratorial and clinical impacts of tobacco on periodontal health: A systematic review. Int Dental J Student's Res 2015; 3(2): 72-8.

[39] Greabu M, Totan A, Battino M, et al. Cigarette smoke effect on total salivary antioxidant capacity, salivary glutathione peroxidase and gamma-glutamyltransferase activity. Biofactors 2008; 33(2): 129-36. 
[http://dx.doi.org/10.1002/biof.5520330205] [PMID: 19346588]

[40] Hasnis E, Bar-Shai M, Burbea Z, Reznick AZ. Mechanisms underlying cigarette smoke-induced NF-kappaB activation in human lymphocytes: the role of reactive nitrogen species. J Physiol Pharmacol 2007; 58(1)(Suppl. 5): 275-87. [PMID: 18204137]

[41] Nakagawa T, Yokozawa T. Direct scavenging of nitric oxide and superoxide by green tea. Food Chem Toxicol 2002; 40(12): 1745-50. [http://dx.doi.org/10.1016/S0278-6915(02)00169-2] [PMID: 12419687]

[42] Chung HY, Yokozawa T, Soung DY, Kye IS, No JK, Baek BS. Peroxynitrite-scavenging activity of green tea tannin. J Agric Food Chem 1998; 46(11): 4484-6.

[http://dx.doi.org/10.1021/jf980556u]

[43] Hirao K, Yumoto H, Nakanishi T, et al. Tea catechins reduce inflammatory reactions via mitogen-activated protein kinase pathways in tolllike receptor 2 ligand-stimulated dental pulp cells. Life Sci 2010; 86(17-18): 654-60. [http://dx.doi.org/10.1016/j.lfs.2010.02.017] [PMID: 20176036]

[44] Kundu JK, Surh YJ. Inflammation: gearing the journey to cancer. Mutat Res 2008; 659(1-2): 15-30. [http://dx.doi.org/10.1016/j.mrrev.2008.03.002] [PMID: 18485806]

[45] Kang SW, Park HJ, Ban JY, Chung JH, Chun GS, Cho JO. Effects of nicotine on apoptosis in human gingival fibroblasts. Arch Oral Biol 2011; 56(10): 1091-7. [http://dx.doi.org/10.1016/j.archoralbio.2011.03.016] [PMID: 21497792]

[46] Weitberg AB, Corvese D. The effect of epigallocatechin galleate and sarcophytol A on DNA strand breakage induced by tobacco-specific nitrosamines and stimulated human phagocytes. J Exp Clin Cancer Res 1999; 18(3): 433-7. [PMID: 10606191]

[47] Cattaneo V, Cetta G, Rota C, et al. Volatile components of cigarette smoke: effect of acrolein and acetaldehyde on human gingival fibroblasts in vitro. J Periodontol 2000; 71(3): 425-32. [http://dx.doi.org/10.1902/jop.2000.71.3.425] [PMID: 10776930]

[48] Beretta G, Furlanetto S, Regazzoni L, Zarrella M, Facino RM. Quenching of $\alpha, \beta$-unsaturated aldehydes by green tea polyphenols: HPLC-ESIMS/MS studies. J Pharm Biomed Anal 2008; 48(3): 606-11. [http://dx.doi.org/10.1016/j.jpba.2008.05.036] [PMID: 18619756]

(C) Khurshid et al.; Licensee Bentham Open.

This is an open access article licensed under the terms of the Creative Commons Attribution-Non-Commercial 4.0 International Public License (CC BY-NC 4.0) (https://creativecommons.org/licenses/by-nc/4.0/legalcode), which permits unrestricted, non-commercial use, distribution and reproduction in any medium, provided the work is properly cited. 